- Sebastião Freitas de Medeiros

- Márcia Marly Winck Yamamoto de Medeiros

- Vivaldo Naves de Oliveira

CONTEXT AND OBJECTIVE: Climacteric symptoms may vary between different countries and cultures. Socioeconomic factors and climate may be implicated. The aim of this study was to identify climacteric symptomatology among very low-income Brazilian women, living in a hot and humid region.

DESIGN AND SETTING: This cross-sectional population-based study was conducted in Cuiabá, at Júlio Müller University Hospital, a tertiary institution.

METHODS: The study enrolled 354 climacteric women. The variables analyzed were social class, symptomatology and abnormal concurrent conditions. The study was approved by the hospital's research ethics committee.

RESULTS: Sixty-five percent of the participants (232/354) were very poor and had had little schooling. The number of symptoms per woman was $8.0 \pm 5.7$. Hot flushes, nervousness, forgetfulness and fatigue were each found in nearly $60.0 \%$. Tearfulness, depression, melancholy and insomnia were also frequent. Sexual problems were reported by $25 \%$. The most relevant concurrent abnormal conditions reported were hypertension $(33.9 \%)$, obesity $(26.5 \%)$, arthritis/arthrosis $(15.0 \%)$ and diabetes mellitus $(9.6 \%)$. Hot flushes were associated with tearfulness, nervousness and forgetfulness.

CONCLUSION: Brazilian climacteric women of low income and low schooling present multiple symptoms. Vasomotor and psychosexual symptoms were the most prevalent disorders. Hot flushes were associated with nervousness, forgetfulness and tearfulness.

KEY WORDS: Climacteric. Social class. Hot flashes. Culture. Tropical climate.

\section{Climacteric complaints among very low-income women from a tropical region of Brazil}

\author{
Hospital Universitário Júlio Müller, Cuiabá, Mato Grosso, Brazil
}

\begin{abstract}
The main initial clinical manifestations of hypoestrogenism are hot flushes, sweating and palpitations. These are associated with fatigue, depression, anxiety, insomnia and forgetfulness. There is some evidence that this early climacteric symptomatology may vary between different countries and cultures. While in most Western societies their prevalence is high, in Oriental society and in other communities where the attitude towards the menopause is positive, the complaints appear to be fewer. ${ }^{1}$ For instance, Japanese women only present low levels of vasomotor symptoms associated with the menopause, and Indian women from Yucatan, in Mexico, may have no relevant symptoms at all..$^{2-4}$ In Brazil, a tropical developing country, the prevalence of vasomotor symptoms in climacteric women has been reported to be as high as $74-84 \%$.,
\end{abstract}

After a few years in a hypoestrogenic state, genitourinary atrophy appears. The most prevalent symptoms at this stage are vaginal dryness, dyspareunia, urinary incontinence and higher frequency of micturition. Worldwide, the reported rates of genital atrophic complaints are between $21 \%$ and $43 \%$ among postmenopausal women, and two out of three women aged of 75 present such complaints. ${ }^{7,8}$ Urinary incontinence has been reported to be between $7.4 \%$ and $73 \%$, and it is more frequent among institutionalized women. ${ }^{9,10}$ In Brazil, there is a lack of information but, in a single study, dyspareunia was found in 31\% and libido loss in $69 \%$ of a climacteric population. ${ }^{11}$

Because of the great variation in the prevalence of these symptoms, it has been suggested that they may be directly or indirectly influenced by preconceived attitudes towards the menopause, different exposure to stressful situations, lifestyle, race or socioeconomic status.
口BJECTIVE

The majority of the current available data was obtained among non-Latin American women or among women of higher socioeconomic level. Here, we put forward the hypothesis that a hot and humid tropical environment may also be relevant. Therefore, the aim of this study was to investigate the extent of and characterize the climacteric symptomatology among urban, mixed race, very low-income women from a tropical region in a developing country.

PATIENTS AND METHODS

This population-based, cross-sectional study was performed at the Júlio Müller Hospital, Universidade Federal de Mato Grosso, in Cuiabá, from June to December 2002. The prevalent symptoms and concurrent abnormal clinical conditions of 354 climacteric women, aged between 40 and 65 years, living in the western district of the city of Cuiabá, were analyzed. Formal consent was obtained from all patients for their participation in this study. The study followed the ethical criteria of the Brazilian Health Council and was approved by the Research Ethics Committee of the Júlio Müller University Hospital.

In determining the sample size, the study design took into consideration an $80 \%$ prevalence of hot flushes, type I error of 5\% $(\alpha=0.05)$ and $5 \%$ imprecision, i.e. a $95 \%$ confidence interval. ${ }^{12}$ Data were recorded on a previously adapted questionnaire used by the Department of Gynecology and Obstetrics of the Federal University of Mato Grosso, Brazil. ${ }^{13}$ The data analysis took into consideration the domains of the patients' identification, anthropometry, medical history and symptomatology.

The sociodemographic variables of race, age, marital status, schooling and occupation were included. The social classes were 
determined by using the schooling level and purchasing power as the indicators, in accordance with the methodology of the Brazilian Association of Market Research Institutes. ${ }^{14}$ Briefly, this classification includes purchasing power, in which all household appliances owned are multiplied by a predetermined weight, the sanitary conditions in the home, and the schooling level. According to the number of points scored, the individual is placed in classes A, B, C, D, or E.

Associations between the variables considered were examined using the $\chi^{2}$ test. The strengths of the associations were estimated using the contingency coefficient (CC). Results were presented as odds ratios $(\mathrm{OR})$ with 95\% confidence intervals (95\% CI). Possible interactions between hot flushes and other symptoms or abnormal clinical conditions were analyzed by logistic regression. Statistical significance in the comparisons was accepted when $\mathrm{p}<0.05$.

\section{RESULTS}

The women's mean age was $49.7 \pm 7$ years. Most of them were married (65.8\%), of mixed race (52\%), and had had less than eight years of schooling $(62.4 \%)$ or were illiterate (19.2\%). About $84.3 \%$ were only occupied with domestic activities. Their mean body weight was $64.5 \pm 13.6 \mathrm{~kg}$ and their mean body mass index (BMI) was $26.7 \pm 5 \mathrm{~kg} / \mathrm{m}^{2}$. Following the World Health Organization classification, $25 \%$ were obese and $4 \%$ were underweight. ${ }^{15}$

Nine percent (32/354) of these climacteric women belonged to social class B, $25 \%$ (90/354) to class C, $58 \%(206 / 354)$ to class D, and $7 \%(26 / 354)$ to class E. Sixty-five percent earned less than 250 United States dollars (US\$) a month. Their characteristics are summarized in Table 1.

The mean number of symptoms presented by each woman was $8.0 \pm 5.7$, ranging from none to a maximum of 19 . Eighty-seven women $(87 / 354 ; 24.6 \%)$ were asymptomatic, 41/354 (11.6\%) reported one to five symptoms, $74 / 354(20.9 \%)$ six to nine symptoms, $107 / 354(30.2 \%)$ ten to fourteen symptoms, and 45/354 (12.7\%) fifteen to nineteen symptoms. The proportions of all signs and symptoms reported are listed in Table 2 . Nearly $60 \%$ of the women complained about hot flushes (206/354), nervousness $(206 / 354)$ or forgetfulness (194/354), while more than $40 \%$ complained of tearfulness (153/354), depression (150/354), melancholy (148/354), insomnia (146/354), asthenia (174/354) and dizziness
(153/354). Sexual problems were of concern for almost $25 \%$ of the women.

At least one concurrent unfavorable clinical condition was reported by 266 of the women $(75.1 \%)$. The most frequent associated diseases were arterial hypertension (120/354; $33.9 \%)$, obesity (33/354; $26.5 \%)$, arthritis/ arthrosis (53/354; 15.0\%), diabetes mellitus (34/354; 9.6\%), heart disease (27/354; 7.6\%), osteoporosis $(25 / 354 ; 7.0 \%)$ and thromboembolic disease $(7 / 354 ; 2.0 \%)$. Hot flushes were present in $90 / 120(77.5 \%)$ of the hypertensive women and only in $135 / 254$ (57.6\%) of the normotensive women $(p=0.003)$. In the nonobese group, 175/259 (67.5\%) complained of hot flushes and, in the obese group, 52/94 $(55.3 \%)$ had this symptom ( $\mathrm{p}=0.034)$. No relationship was found between hot flushes and diabetes mellitus $(\mathrm{p}=0.546)$ or type of menopause $(p=0.480)$.

There was an association between hot flushes and age, thus showing that this symptom was more prevalent among women aged over 49 ( $p<0.001)$. In addition, hot flushes showed strong positive relationships $(\mathrm{p}<0.05)$ with nervousness (OR: 38.2; 95\% CI: 20.172.3), forgetfulness (OR: 15.7; 95\% CI: 9.027.3), insomnia (OR: 15.1; 95\% CI: 8-29.4) and libido loss (OR: 3.0; 95\% CI: 1.7-5.1). However, logistic regression with adjusted odds ratios did not confirm the existence of any association between hot flushes and libido loss ( $\mathrm{p}=0.292$; Table 3$)$.

\section{DISCUSSIRN}

The present paper is the first to describe the climacteric symptoms among women living in the southern part of the Amazon region. This population living in a hot and humid region of Brazil was characterized by very low socioeconomic level and income of less than US\$250/month. The number of symptoms reported by each woman in this Brazilian population was high. Nervousness, hot flushes, forgetfulness and asthenia were the most frequent complaints. The finding of at least eight symptoms per women is lower than what has been found among Chilean women, ${ }^{16,17}$ or in Pakistan, another developing tropical country, where the number of symptoms per women was even higher, and also related to the low socioeconomic level. ${ }^{18}$ The differences seen in these countries may involve culture, climate or even the different criteria used for determining social class.

Hot flushes were present in $58 \%$ of the women in the current study. Climacteric women from São Paulo city, with similar so-
Table 1. Social and demographic characteristics of Brazilian climacteric women in Cuiabá

\begin{tabular}{lcc}
\hline Characteristic & $\mathbf{n}$ & $\%$ \\
\hline Marital status & & \\
Single & 37 & 10.5 \\
Married & 233 & 65.8 \\
Widowed & 48 & 13.6 \\
Divorced & 36 & 10.1 \\
\hline Race & & \\
White & 170 & 48.0 \\
Black & 83 & 23.5 \\
Other & 101 & 28.5 \\
\hline Schooling & & \\
Illiterate & 68 & 19.2 \\
Primary school, unfinished & 221 & 62.4 \\
Primary school, complete & 13 & 3.7 \\
High school, unfinished & 13 & 3.7 \\
High school, complete & 10 & 2.8 \\
College/university & 29 & 8.2 \\
\hline Social class & & \\
A & 00 & 0.0 \\
B & 32 & 9.0 \\
C & 90 & 25.4 \\
D & 206 & 58.2 \\
E & 26 & 7.4 \\
\hline
\end{tabular}

cioeconomic characteristics, presented a rate of hot flushes of between $74 \%$ and $84 \%{ }^{6}$ This high prevalence of vasomotor symptoms in Brazil does not differ from observations already made in several developed countries. ${ }^{19}$ Nevertheless, comparisons of the prevalence rates of hot flushes between countries have shown up remarkable differences that are currently attributed to dietary factors and cultural beliefs or social norms. ${ }^{1}$ Despite the high worldwide prevalence, low rates have been found in many Asian countries. ${ }^{2}$ Hot flushes are even absent among some Indian and Mexican groups. There is strong evidence that the diet consumed in Asian countries, which is rich in phytoestrogens, may decrease vasomotor symptoms. However, in some Asian countries with very similar diet, frequencies of hot flushes of up to $30-50 \%$ have been found. ${ }^{20}$ In Brazil, where the diet of lowincome people is also rich in rice, beans and cassava (manioc) flour, a very high prevalence of hot flushes is seen nationwide. The bearing of this humid, high-temperature and muggy environment on the appearance of vasomotor symptoms has not been measured yet. Further studies evaluating the hypothesis that a tropical environment may modulate the appearance of hot flushes are needed.

Neuropsychiatric symptoms such as forgetfulness, nervousness and depression 
Table 2. Symptomatology reported by low-income Brazilian climacteric women in Cuiabá

\begin{tabular}{|c|c|c|c|}
\hline Category & Symptoms/signs* & $\mathbf{N}$ & $\% \dagger$ \\
\hline \multirow{4}{*}{ Vasomotor } & Hot flushes & 206 & 58.2 \\
\hline & Palpitations & 153 & 43.2 \\
\hline & Dizziness & 153 & 43.2 \\
\hline & Sweating & 120 & 33.9 \\
\hline \multirow{7}{*}{ Psychiatric } & Nervousness & 206 & 58.2 \\
\hline & Forgetfulness & 194 & 54.8 \\
\hline & Tearfulness & 153 & 43.2 \\
\hline & Depression & 150 & 42.4 \\
\hline & Melancholy & 148 & 41.8 \\
\hline & Insomnia & 146 & 41.2 \\
\hline & Nostalgia & 55 & 15.5 \\
\hline \multirow{2}{*}{ Sexual } & Libido loss & 111 & 31.1 \\
\hline & Dyspareunia/vaginal dryness & 102 & 28.8 \\
\hline \multirow{2}{*}{ Urinary } & Urinary incontinence & 75 & 21.2 \\
\hline & Pollakiuria & 69 & 19.5 \\
\hline \multirow{2}{*}{ Skeleton muscle } & Myalgia & 137 & 38.7 \\
\hline & Arthralgia & 135 & 38.1 \\
\hline \multirow{5}{*}{ Others } & Asthenia & 174 & 49.2 \\
\hline & Formication & 126 & 35.6 \\
\hline & Hair loss & 123 & 34.7 \\
\hline & Headache & 79 & 22.3 \\
\hline & Hair growth increase & 37 & 10.5 \\
\hline
\end{tabular}

*More than one symptom per woman was reported; $\uparrow$ The percentage presented was estimated by considering all 354 women. were seen in this study twice as frequently as reported from southern Brazil. ${ }^{21}$ While the population in the present study was poor and largely composed of non-white women, the women analyzed by Cassol in southern Brazil were essentially Caucasian European migrants and their descendants, of better socioeconomic level. Two other Brazilian studies, conducted in the south and on the southeast coast, demonstrated even more neuropsychiatric disorders. The differences are not clear yet, but the later studies were conducted in the most developed Brazilian states. ${ }^{11,22}$ The neuropsychiatric symptom rates found in these studies ranged from $40 \%$ to $70 \%$ did not, however, seem much higher than earlier reports from other cultures. In China, neuropsychiatric symptoms have been seen at a rate of up to $46 \% .{ }^{23}$ In other cross-sectional studies, the rates of psychiatric manifestations among climacteric women have ranged from $25 \%$ to $40 \%{ }^{24}$ Although the menopause in itself does not appear to be the cause of such psychiatric modifications, changes related to the time around the menopause have been observed in up to $10 \%$ of the women included in prospective epidemiological studies. ${ }^{25}$

The sexual symptoms of loss of libido, dyspareunia and vaginal dryness were reported in one third of the climacteric women in the present study. A dyspareunia rate of as high as $31 \%$ had already been reported from southern Brazil. ${ }^{22}$ It has also been reported in $45 \%$ of Chilean climacteric women. ${ }^{17}$ Libido loss, dyspareunia, burning sensations and vaginal dryness are matters of concern for between $40 \%$ and $54 \%$ of climacteric women in the United States ${ }^{26}$ and Europe. ${ }^{8}$ Although the differences in prevalences are not clearly understood yet,

Table 3. Association between hot flushes and psychosexual complaints among low-income Brazilian climacteric women in Cuiabá

\begin{tabular}{|c|c|c|c|c|c|c|c|c|c|c|}
\hline \multirow{2}{*}{$\begin{array}{l}\text { Psychosexual } \\
\text { symptoms }\end{array}$} & & \multicolumn{2}{|c|}{ Hot flushes } & \multicolumn{4}{|c|}{ Bivariate analysis } & \multicolumn{3}{|c|}{ Logistic regression } \\
\hline & & Yes & No & $\chi^{2}$ & ${ }^{\circ} \mathrm{CC}$ & $\begin{array}{c}\text { OR } \\
(95 \% \mathrm{Cl})\end{array}$ & p & aOR & $95 \% \mathrm{Cl}$ & $\mathbf{p}$ \\
\hline \multirow{2}{*}{ Nervousness } & Yes & 191 (83.8) & $15(16.2)$ & 172.2 & 0.572 & $\begin{array}{c}38.2 \\
(20.1-72.3)\end{array}$ & 0.000 & 12.9 & $5.3-31.8$ & 0.000 \\
\hline & No & $37(25.0)$ & $111(75.0)$ & & & & & & & \\
\hline \multirow{2}{*}{ Insomnia } & Yes & $135(92.5)$ & $11(7.5)$ & 85.3 & 0.441 & $\begin{array}{c}15.1 \\
(7.8-29.4)\end{array}$ & 0.000 & 3.2 & $1.1-9.0$ & 0.028 \\
\hline & No & $93(44.7)$ & $115(55.3)$ & & & & & & & \\
\hline \multirow{2}{*}{ Forgetfulness } & Yes & $173(89.2)$ & $21(10.8)$ & 114.8 & 0.495 & $\begin{array}{c}15.7 \\
(9.0-27.3)\end{array}$ & 0.000 & 6.5 & $0.6-15.9$ & 0.000 \\
\hline & No & $55(34.4)$ & $105(65.6)$ & & & & & & & \\
\hline \multirow{2}{*}{ Libido loss } & Yes & $89(80.2)$ & $22(19.8)$ & 17.5 & 0.217 & $\begin{array}{l}3.0 \\
(1.7-5.1)\end{array}$ & 0.000 & 0.6 & $0.2-1.5$ & 0.292 \\
\hline & No & $139(57.2)$ & $104(42.8)$ & & & & & & & \\
\hline
\end{tabular}

${ }^{*} \mathrm{CC}=$ contingency coefficient; $\mathrm{OR}=$ odds ratio; $\mathrm{Cl}=$ confidence interval; $a \mathrm{OR}=$ adjusted odds ratio. 
they have also been attributed to different inclusion criteria, the women's ages and cultural factors. ${ }^{26} \mathrm{~A}$ distinction between urinary incontinence and urgency was not made in the present study, because of the epidemiological design. However the observed rate of $21 \%$ in the current report is in agreement with the majority of publications worldwide.

A few studies have examined factors that could predispose women to hot flushes, and it has been accepted that hot flushes can be modulated by psychosocial factors. ${ }^{27,28}$ Nervousness, forgetfulness, insomnia and libido loss were associated with vasomotor symptoms in the current study. In a logistic regression model, taking the combined effect of all these variables on hot flushes, only libido loss did not retain an independent association with vasomotor symptoms (adjusted OR: 0.6; 95\% CI: 0.2-1.5).

\section{CONCLUSION}

Most participants in this study had had little schooling and presented very low socioeconomic status, and they present multiple climacteric symptoms. These features of the sample studied may limit the findings from the current study to populations with the same characteristics. Women who are also sampled from the general population but who belong to higher social classes and have had greater schooling should also be studied in order to fully understanding the perception of symptoms relating to the menopause among Brazilian women. In addition, further studies focusing on the tropical environment and local dietary practices should be conducted in order to determine whether or not these variables might influence menopausal symptoms.
1. Medeiros SF, Oliveira VN, Yamamoto MMW. Epidemiologia clínica do climatério. [Clinical epidemiology of climacteric]. Reprod Clim. 2003;18:79-86.

2. Obermeyer CM. Menopause across cultures: a review of the evidence. Menopause. 2000;7(3):184-92.

3. Lock M, Kaufert P, Gilbert P. Cultural construction of the menopausal syndrome: the Japanese case. Maturitas. 1988;10(4):317-32.

4. Martin MC, Block JE, Sanchez SD, Arnaud CD, Beyene Y. Menopause without symptoms: the endocrinology of menopause among rural Mayan Indians. Am J Obstet Gynecol. 1993;168(6 Pt 1):1839-43; discussion 1843-5.

5. Baracat EC, Bortoletto CCR, Nunes MG, et al. Síndrome do climatério: aspectos epidemiológicos. GO. 1995;4(5)27:30.

6. Halbe HW, Fonseca AM, Assis JS, et al. Aspectos epidemiologicos e clinicos em 1.319 pacientes climatericas. [Epidemiological and clinical findings in 1319 pos-menopausal woman]. Rev Ginecol Obstet. 1990;1(3):182-94.

7. Berg G, Gottwall M, Hammar M, Lindgren R. Climacteric symptoms among women aged 60-62 in Linköping, Sweden, in 1986. Maturitas. 1988;10(3):193-9.

8. Stenberg A, Heimer G, Ulmesten U, Cnattingius S. Prevalence of genitourinary and other climacteric symptoms in 61-year-old women. Maturitas. 1996;24(1-2):31-6.

9. Barlow DH, Samsioe G, van Geelen JM. A study of European womens' experience of the problems of urogenital ageing and its management. Maturitas. 1997;27(3):239-47.

10. Ouslander JG. Geriatric urinary incontinence. Dis Mon. 1992;38(2):65-149.

11. De Pelegrin GCL, Novaczyk AA, Winck CHL, Piovezan CM. Avaliação dos sintomas clínicos das pacientes climatéricas atendidas no HUSM em relaçăo ao uso de terapia de reposição hormonal e índice de massa corpórea. Reprod Clim. 1997;12(supl. 1):24. [abstract]. Presented at: Congresso Brasileiro de Climatério \& Menopausa 3 and Congresso Brasileiro de Ginecologia Endócrina 1. Porto Alegre, Jun 18-21, 1997.

12. Katz DL. Sample size, randomization, and probability theory. In: Katz DL, editor. Epidemiology biostatistics and preventive medicine review. Philadelphia: WB Saunders; 1997. p. 97-105.
13. The North American Society. Menopause Health Questionnaire. Available from URL: http://www.menopause.org/edumaterials/pquestionnaire.htm. Accessed in 2006 (May 15).

14. Mattar FN. Análise crítica dos estudos de estratificação sócioeconômica de ABA-Abipeme. Revista de Admininstraçāo. 1995;30(1):57-74. Disponível em: http://www.fauze.com. $\mathrm{br} /$ artigo 10.htm. Accessed in 2006 (Jul 13).

15. Deurenberg P, Yap M. The assessment of obesity: methods for measuring body fat and global prevalence of obesity. Baillieres Best Pract Res Clin Endocrinol Metab. 1999;13(1):1-11.

16. Blumel JE, Brandt A, Tacla X. Perfil sintomatico de la mujer climaterica. Experiencia clinica. [Symptomatic profile of the climacteric female. Clinical experience. Rev Med Chil. 1992;120(9):1017-21.

17. Blumel MJE, Roncagliolo MME, Gramegna Sougarret GM, Tacla FX, Sepúlveda MH, Brandt Alvear A. Prevalência de síntomas psiquicos y vasomotores en diferentes periodos del climaterio. [Prevalence of vasomotores and psychic symptoms in different periods of the climateric. Rev Chil Obstet Ginecol. 1997;62(6):412-8.

18. Wasti S, Robinson SC, Akthar Y, Khan S, Badaruddin N. Characteristics of menopause in three socioeconomic urban groups in Karachi, Pakistan. Maturitas. 1993;16(1):61-9.

19. Whiteman MK, Staropoli CA, Benedict JC, Borgeest C, Flaws JA. Risk factors for hot flashes in midlife women. J Women Health (Larchmt). 2003;12(5):459-72.

20. Boulet MJ, Oddens BJ, Lehert P, Vemer HM, Visser A. Climacteric and menopause in seven South-east Asian countries. Maturitas. 1994;19(3):157-76.

21. Cassol G, Silva PB, Pinto CS, et al. Avaliação da depressão no climatério utilizando a escala de Zung. Reprod Clim. 1997;12(suppl 1):25. [abstract]. Presented at: Congresso Brasileiro de Climatério \& Menopausa 3 and Congresso Brasileiro de Ginecologia Endócrina 1. Porto Alegre, Jun 18-21, 1997.

22. Almeida AB, Almeida SB, Rechden CL, Marques AL, Nervo CC. Incidência dos sintomas das pacientes do ambulatório de climatério da ISCMPA. Reprod Clim. 1997;12(supl. 1):35. [abstract]. Presented at: Congresso Brasileiro de Climatério \& Menopausa 3 and Congresso Brasileiro de Ginecologia Endócrina 1. Porto Alegre, Jun 18-21, 1997.
23. Liu P, He FF, Bai WP, et al. Menopausal depression: comparison of hormone replacement therapy and hormone replacement therapy plus fluoxetine. Chin Med J (Engl). 2004;117(2):189-94.

24. Hunter M, Battersby R, Whitehead M. Relationships between psychological symptoms, somatic complaints and menopausal status. Maturitas. 1986;8(3):217-28.

25. Hunter MS. Predictors of menopausal symptoms: psychosocial aspects. Baillieres Clin Endocrinol Metab. 1992;7(1):33-45.

26. Bachmann GA. Influence of menopause on sexuality. Int J Fertil Menopausal Stud. 1995;40(Suppl 1):16-22.

27. Freeman EW, Sammel MD, Lin H, Gracia CR, Kapoor S, Ferdousi T. The role of anxiety and hormonal changes in menopausal hot flashes. Menopause. 2005;12(3):258-66.

28. Binfa L, Castelo-Branco C, Blumel JE, et al. Influence of psycho-social factors on climacteric symptoms. Maturitas. 2004;48(4):425-31.

Sources of funding: Not declared Conflict of interest: Not declared

Date of first submission: September 22, 2005

Last received: July 12, 2006

Accepted: July 17, 2006 


\section{AUTHOR INFORMATION}

Sebastião Freitas de Medeiros, MD, PhD. Tropical Institute of Reproductive Medicine and Climacteric, Climacteric Clinic, Júlio Müller University Hospital, Department of Gynecology and Obstetrics, Faculdade de Ciências Médicas da Universidade Federal de Mato Grosso, Cuiabá, Mato Grosso, Brazil.

Márcia Marly Winck Yamamoto de Medeiros, MD. Tropical Institute of Reproductive Medicine and Climacteric, Cuiabá, Mato Grosso, Brazil

Vivaldo Naves de Oliveira, MD. Department of Gynecology and Obstetrics, Faculdade de Ciências Médicas da Universidade Federal de Mato Grosso, Cuiabá, Mato Grosso, Brazil

\section{Address for correspondence:}

Sebastião Freitas de Medeiros

Rua Marechal Deodoro, 1055, Apto. 1302

Centro

Cuiabá (MT) - Brasil - CEP 78005-101

Tel. (+55 65) 3615-7330 - Fax (+55 65) 3612-9090

E-mail: de.medeiros@terra.com.br

\section{Sintomas climatéricos em mulheres com baixa renda de uma região tropical do Brasil}

RESUMD

CONTEXTO E OBJETIVO: Sintomas climatérios podem mudar em diferentes culturas e países. Aspectos sócio-econômicos e clima podem estar envolvidos. Este estudo tem como proposta identificar os sintomas em mulheres climatéricas brasileiras de baixa renda de uma região quente e úmida do Brasil.

TIPO DE ESTUDO E LOCAL: Estudo de coorte transversal, realizado no Hospital Universitário Julio Muller em Cuiabá.

MÉTODOS: Este estudo incluiu todas as 354 mulheres climatéricas do Distrito Oeste de Cuiabá. Incluiuse na análise as variáveis classe social, sintomas e doenças coexistentes. Possíveis associações foram examinadas pelo teste $\chi^{2}$ e regressão logística.

RESULTADOS: $65 \%$ das pacientes eram muito pobres e de baixa escolaridade. O número médio de sintomas referidos por mulher foi de $8.0 \pm 5.7$. Fogachos, nervosismo, esquecimento e fadiga foram encontrados em quase $60 \%$ das mulheres. Choro imotivado, melancolia, depressão e insônia também foram freqüentes. Disfunções sexuais foram relatadas por cerca de $25 \%$ das mulheres. Fogachos foram associados com esquecimento, nervosismo e choro imotivado. As doenças coexistentes mais freqüentes foram hipertensão arterial $(33,9 \%)$, obesidade $(26,5 \%)$, artrite/artrose $(15,0 \%)$ e diabetes mellitus $(9,6 \%)$.

CONCLUSÃO: Mulheres climatéricas brasileiras de baixa renda e baixa escolaridade são plurisintomáticas. Os sintomas vasomotores e psicosexuais foram os mais prevalentes. Fogachos foram associados a nervosismo, esquecimento e choro imotivado.

PALAVRA-CHAVE: Climatério. Classe social. Fogachos. Cultura. Clima tropical. 